Al Qalam: Jurnal Ilmiah Keagamaan dan Kemasyarakatan https://jurnal.stiq-amuntai.ac.id/index.php/al-qalam

P-ISSN: 1907-4174; E-ISSN: 2621-0681

DOI: 10.35931/aq.v14i1.349

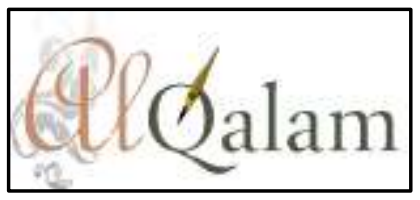

\title{
IMPLEMENTASI KEGIATAN EKSTRAKURIKULER DALAM MENANAMKAN KARAKTER RELIGIUS DI MADRASAH TSANAWIYAH DARUL AMANAH DESA PANDAHAN KECAMATAN BATI-BATI
}

\author{
Oleh: \\ Asep Saefuloh ${ }^{1}$, Imaniah Elfa Rachmah ${ }^{2}$, Muhamad Ramli $^{3}$ \\ Dosen Sekolah Tinggi Agama Islam Al Falah Banjarbaru \\ e-mail: asepsaefuloh001@gmail.com¹,ima.pps2011@gmail.com², \\ ramlimuhamad408@gmail.com ${ }^{3}$
}

\begin{abstract}
This research discusses the implementation of extracurricular activities in instilling religious character in Madrasah Tsanawiyah Darul Amanah Pandahan Village, Bati-Bati District. The purpose of this study was to determine the implementation of extracurricular activities in instilling religious character in Madrasah Tsanawiyah Darul Amanah Pandahan Village, Bati-Bati District, and the supporting and inhibiting factors that influence these activities. The subjects in this study were three coaches of extracurricular activities, while the object in this study was the implementation of extracurricular activities in instilling religious character and the factors that support and hinder the implementation of these activities. In extracting data, researchers used observation, interview, and documentation techniques. Data management techniques are done by editing, data classification, and data interpretation. Then analyzed with qualitative descriptive analysis and inductive conclusions drawn. Based on the research results, it is known that the implementation of extracurricular activities in Madrasah Tsanawiyah Darul Amanah has been going well. The implementation of extracurricular activities is influenced by supporting factors, namely educational background factors and the personality of teachers who teach in these extracurricular activities as well as the Islamic community environment so that the implementation of extracurricular activities in instilling religious character can run well.
\end{abstract}

Keywords: Implementation, Learning Process, Character Education. 
Asep Saefuloh, Imaniah Elfa Rachmah, Muhamad Ramli: Implementasi Ekstrakurikuler Dalam Menanamkan Karakter Religius Di Madrasah Tsanawiyah Darul Amanah Desa Pandahan Kecamatan Bati-Bati

\begin{abstract}
ABSTRAK
Penelitian ini membahas tentang implementasi kegiatan ekstrakurikuler dalam menanamkan karakter religius di Madrasah Tsanawiyah Darul Amanah Desa Pandahan Kecamatan Bati-Bati. Tujuan penelitian ini adalah untuk mengetahui implementasi kegiatan ekstrakurikuler dalam menanamkan karakter religius di Madrasah Tsanawiyah Darul Amanah Desa Pandahan Kecamatan Bati-Bati serta faktor pendukung dan penghambat yang mempengaruhi kegiatan tersebut. Subjek dalam penelitian ini adalah tiga orang pembina kegiatan ekstrakurikuler, adapun objek dalam penelitian ini adalah implementasi kegiatan ekstrakurikuler dalam menanamkan karakter religius serta faktor-faktor yang mendukung dan menghambat implementasi kegiatan tersebut. Dalam penggalian data, peneliti menggunakan teknik observasi, wawancara dan dokumentasi. Teknik pengelolaan data dilakukan dengan editing, klasifikasi data dan interpretasi data. Selanjutnya dianalisis dengan analisa deskriptif kualitatif dan ditarik simpulan secara induktif. Berdasarkan hasil penelitian, diketahui bahwa implementasi kegiatan esktrakurikuler di Madrasah Tsanawiyah Darul Amanah telah berjalan dengan baik. Implementasi kegiatan ekstrakurikuler tersebut dipengaruhi oleh faktorfaktor pendukung, yaitu faktor latar belakang pendidikan dan kepribadian guru yang mengajar pada kegiatan ekstrakurikuler tersebut serta lingkungan masyarakat yang islami sehingga pelaksanaan kegiatan esktrakurikuler dalam menanamkan karakter religius dapat berjalan dengan baik.
\end{abstract}

Kata kunci: Implementasi, Proses Pembelajaran, Pendidikan Karakter.

\title{
A. PENDAHULUAN
}

Pendidikan bagi kehidupan manusia merupakan suatu kebutuhan yang harus dipenuhi sepanjang hidupnya. Oleh karenanya pendidikan tidak dapat terlepas dari kehidupan seseorang. Dengan pendidikan manusia dapat mengembangkan diri untuk memperkaya pengetahuan dan keterampilan untuk menghadapi perkembangan zaman. Allah memuliakan hambanya yang berpengetahuan melalui firmannya pada surah al-Mujadalah Ayat 11.

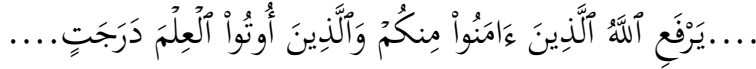

Artinya: ...Niscaya Allah akan meninggikan orang-orang yang beriman di antaramu dan orang-orang yang diberi ilmu pengetahuan beberapa derajat.” (Q.S. Al-Mujadalah: 11)

Ayat tersebut merupakan suatu motivasi bagi orang muslim untuk senantiasa belajar dan mencari ilmu pengetahuan. Ibnu Abbas 
Asep Saefuloh, Imaniah Elfa Rachmah, Muhamad Ramli: Implementasi Ekstrakurikuler Dalam Menanamkan Karakter Religius Di Madrasah Tsanawiyah Darul Amanah Desa Pandahan Kecamatan Bati-Bati

mengungkapkan kemuliaan seorang ulama atas orang mu'min pada umumnya terlampau tujuh ratus derajat, setiap dua derajat seumpama jarak perjalanan lima ratus tahun. Keutamaan menuntut ilmu juga disabdakan oleh Nabi Muhammad SAW. Yang diriwayatkan oleh Abu Hurairah R.A.

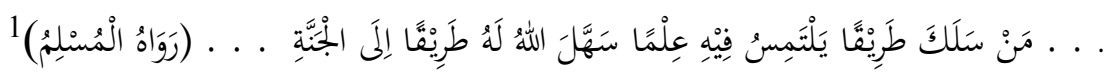

Artinya: "Barangsiapa yang menempuh suatu jalan untuk menuntut ilmu maka akan Allah mudahkan baginyajalan menuju surga." (HR. Muslim). Pada hakikatnya orang tua memiliki peran penting dalam mendidik anaknya karena keluarga merupakan tempat pendidikan pertama yang dia dapatkan. Namun, tidak semua tugas pendidikan dapat dilaksanakan oleh orang tua dalam keluarga terutama dalam hal ilmu pengetahuan dan berbagai keterampilan. Oleh karena itu anak-anak dikirim ke sekolah sebagai peserta didik. Selain mengajarkan ilmu pengetahuan sekolah juga diberikan tanggung jawab untuk menanamkan karakter yang baik dalam diri peserta didik.

Menurut Abdul Majid karakter diartikan sebagai tabi'at watak sifat-sifat kejiwaan, akhlak atau budi pekerti yang membedakan seseorang dengan orang lain. ${ }^{2}$ Sedangkan menurut Kemendiknas karakter adalah watak, tabiat, akhlak dan kepribadian seseorang yang terbentuk dari implementasi berbagai kebijakan dan keyakinan yang digunakan sebagai landasan berfikir, bersikap dan bertindak. Sementara pendidikan karakter diartikan pendidikan yang mengembangkan nilai-nilai karakter bangsa pada diri peserta didik, sehingga mereka memiliki nilai dan karakter sebagai dirinya, menerapkan nilai-nilai tersebut dalam kehidupan dirinya, sebagai anggota masyarakat, dan warga negara yang religius, nasionalis, produktif dan kreatif. ${ }^{3}$

Karakter merupakan hal yang sangat penting dan mendasar. Sejak tahun 2011 Kementrian Pendidikan Nasional mengusung 18 karakter sesuai dengan Pancasila yaitu 1) Religius, 2) Jujur, 3) Toleransi, 4) Disiplin, 5) Kerja Keras, 6) Kreatif, 7) Mandiri, 8) Demokratis, 9) Rasa Ingin Tahu, 10) Semangat, 11) Cinta Tanah Air, 12) Menghargai Prestasi, 13) Bersahabat/Komunikatif, 14) Cinta Damai, 15) Gemar Membaca, 16) Peduli lingkungan, 17) Peduli Sosial, 18) Tanggung Jawab. ${ }^{4}$

\footnotetext{
${ }^{1}$ Yahya bin Syarf an-Nawawi, Sahih Muslim bi Syarh an-Nawawi, (Beirut: Dar al-Kutub al-Ilmiyah, 2015), Cet ke-6, Jilid 17, h. 18

${ }^{2}$ Abdul Majid dan Dian Anayani, Pendidikan Karakter Perspektif Islam, (PT. Remaja Rosdakarya, 2013), h. 10

${ }^{3}$ Kemendiknas, Pedoman Sekolah Pengembangan Pendidikan Budaya dan Karakter Bangsa, (Jakarta: Balitbang, 2010), h. 8

${ }^{4}$ Kemendiknas, Pedoman Sekolah Pengembangan Pendidikan ..., h. 9
} 
Asep Saefuloh, Imaniah Elfa Rachmah, Muhamad Ramli: Implementasi Ekstrakurikuler Dalam Menanamkan Karakter Religius Di Madrasah Tsanawiyah Darul Amanah Desa Pandahan Kecamatan Bati-Bati

Pembahasan mengenai pendidikan karakter telah disebutkan juga dalam sistem pendidikan nasional yang perlu diaplikasikan oleh setiap sekolah sehingga diharapkan akan terbentuk suatu karakter siswa yang baik. Pendidikan di indonesia diatur melalui perundang-undangan. Dalam pasal 1 ayat 1 Undang-Undang Nomor 20 Tahun 2003 tentang Sistem Pendidikan Nasional, bahwa:

Pendidikan adalah usaha sadar dan terencana untuk mewujudkan suasana belajar dan proses pembelajaran agar peserta didik secara aktif mengembangkan potensi dirinya untuk memiliki kekuatan spiritual keagamaan, pengendalian diri, kepribadian, kecerdasan, akhlak mulia, serta keterampilan yang diperlukan dirinya, masyarakat, bangsa dan negara. ${ }^{5}$

Sistem pendidikan nasional tersebut merupakan pijakan umum yang digunakan oleh setiap institusi atau lembaga-lembaga pendidikan. Dalam setiap pendidikan ini harus terjadi kesatuan gerak antar komponen yang bisa mengantarkan atau menjembatani terwujudnya tujuan pendidikan nasional. Peserta didik menempati posisi yang strategis karena ia menjadi subyek yang dididik dan dikembangkan, sehingga dharapkan menjadi manusia yang berguna. Peserta didik bukan hanya dididik untuk menjadi manusia yang cakap, pintar dan berilmu, tetapi juga dibentuk pribadinya supaya menjadi sosok yang beriman ${ }^{6}$.

Baik dan tidaknya karakter suatu bangsa dapat dilihat dari pemuda dan remajanya. Masa remaja merupakan masa transisi dari masa anak-anak ke masa awal dewasa. Peserta didik pada usia remaja perlu mendapatkan bimbingan lebih dalam hal karakter melalui berbagai kegiatan positif terlebih dalam hal baik yang diminatinya karena pada masa itu peserta didik sedang mencari jati dirinya.

Pendidikan di Indonesia memiliki berbagai tingkatan sesuai dengan kebutuhan peserta didik. Dalam setiap tingkatan tersebut memiliki bobot pendidikan yang berbeda. Lembaga pendidikan Islami lanjutan dari Madrasah Ibtidaiyah dan Sekolah Dasar adalah Madrasah Tsanawiyah. Madrasah Tsanawiyah merupakan tingkat pendidikan formal yang mendidik usia remaja. pendidikan di Madrasah Tsanawiyah merupakan langkah penting dalam merubah prilaku keagamaan peserta didik remaja melalui proses belajar mengajar di kelas, maupun proses praktik di luar kelas.

Lembaga pendidikan menawarkan berbagai kegiatan esktrakurikuler yang dilaksanakan di luar jam pelajaran. Adanya ekstrakurikuler di sekolah bertujuan untuk mengembangkan kepribadian,

\footnotetext{
${ }^{5}$ Departemen Pendidikan Nasional, Undang-Undang No. 20 Tahun 2003

Tentang Sistem Pendidikan Nasional, (Bandung: Citra Umbara, 2003), h. 12

${ }^{6}$ Bashori Muchsin dan Abdul Wahid, Pendidikan Islam Kontemporer, (Bandung: PT. Reflika Aditama, 2009), h. 23
} 
Asep Saefuloh, Imaniah Elfa Rachmah, Muhamad Ramli: Implementasi Ekstrakurikuler Dalam Menanamkan Karakter Religius Di Madrasah Tsanawiyah Darul Amanah Desa Pandahan Kecamatan Bati-Bati

bakat, keilmuan, keterampilan diluar bidang akademik. Pramuka, Palang Merah Remaja (PMR), Rohani Islam (Rohis), Drum Band merupakan beberapa contoh dari kegiatan ekstrakurikuler.

Madrasah Tsanawiyah Darul Amanah merupakan salah satu lembaga penyelenggara pendidikan di Desa Pandahan Kecamatan BatiBati. Sebagaimana Madrasah Tsanawiyah pada umumnya, Madrasah Tsanawiyah Darul Amanah dalam mengembangkan minat dan bakat peserta didiknya memiliki kegiatan ekstrakurikuler. Ekstrakurikuler keagamaan merupakan salah satu kegiatan ekstrakurikuler yang ditawarkan kepada pelajar di Madrasah Tsanawiyah Darul Amanah.

Pada awalnya kegiatan ekstrakurikuler tersebut terpacu oleh hadirnya Madrasah Diniah sebagai lembaga non formal yang mempelajari berbagai pelajaran kitab kuning serta kegiatan keagamaan yang lazimnya dipelajari oleh santri di pesantren. Seiring dengan berjalannya waktu, Madrasah Diniah memiliki santri dari berbagai tinggakan pendidikan, termasuk sebagian besar dari pelajar di Madrasah Tsanawiyah Darul Amanah itu sendiri. Mengetahui antusiasme pelajar yang begitu tinggi ketika mengikuti kegiatan di Madrasah Diniah, maka dewan guru di Madrasah Tsanawiyah Darul Amanah bersepakat untuk menghadirkan kegiatan Ekstrakurikuler khusus sebagai wadah mengembangkan pelajar madrasah dalam bidang keagamaan berbasis pendidikan kitab kuning dan berbagai kegiatan keagamaan.

Adanya berbagai ekstrakurikuler di sekolah merupakan hal yang wajar, tetapi hal yang menarik dari Madrasah Tsanawiyah Darul Amanah adalah dengan adanya kegiatan ekstrakurikuler keagamaan. Berdasarkan wawancara dengan bapak $\mathrm{R}$ beliau mengungkapkan bahwa Madrasah Tsanawiyah Darul Amanah memiliki beberapa kegiatan esktrakurikuler, salah satunya adalah Ekstrakurikuler keagamaan yang membantu sekolah dalam menjalankan tugas untuk menanamkan karakter religius pada peserta didik. Pada kegiatan ekstrakurikuler ini, peserta didik akan mempelajari kitab-kitab klasik serta melaksanakan kegiatan keagamaan, sehingga melalui kegiatan pembelajaran dan keagamaan, siswa diharapkan dapat menjadi pribadi yang religius ${ }^{7}$. Melalui pemaparan diatas, penulis merasa tertarik untuk melakukan penelitian pada madrasah tersebut mengenai implementasi kegiatan ekstrakurikuler dalam menanamkan karakter religius di Madrasah Tsanawiyah Darul Amanah Desa Pandahan Kecamatan Bati-Bati.

${ }^{7}$ Bapak R/Kepala Madrasah Tsanawiyah Darul Amanah, Wawancara Pribadi, Madrasah Tsanawiyah Darul Amanah Desa Pandahan Kecamatan Batibati 10 September 2019.

Al Qalam: Jurnal Ilmiah Keagamaan dan Kemasyarakatan Vol. 14, No. 1, Januari-Juni 2020 
Asep Saefuloh, Imaniah Elfa Rachmah, Muhamad Ramli: Implementasi Ekstrakurikuler Dalam Menanamkan Karakter Religius Di Madrasah Tsanawiyah Darul Amanah Desa Pandahan Kecamatan Bati-Bati

\section{B. METODE PENELITIAN}

Jenis penelitian ini dilakukan dalam bentuk penelitian lapangan atau field research yang dilakukan di Madrasah Tsanawiyah Darul Amanah Desa Pandahan Kecamatan Bati-Bati Kabupaten Tanah Laut, karena penelitian dikonsentrasikan untuk menjelaskan kenyataan-kenyataan di lapangan dengan pendekatan kualitatif. Pendekatan kualitatif yaitu prosedur penelitian yang menghasilkan data deskriptif berupa kata-kata tertulis atau lisan dari orang-orang dan prilaku yang diamati. ${ }^{8}$ Sesuai dengan permasalahan yang diangkat dalam penelitian ini, maka yang menjadi subjek dalam penelitian ini adalah tiga pembina kegiatan Ekstrakurikuler. Objek dalam penelitian ini adalah implementasi kegiatan ekstrakurikuler dalam menanamkan karakter religius serta faktor-faktor yang mendukung dan menghambat implementasi kegiatan ekstrakurikuler dalam menanamkan karakter religius di Madrasah Tsanawiyah Darul Amanah Desa Pandahan Kecamatan Bati-Bati.

Teknik pengumpulan data dilakukan melalui observasi, Interview/wawancara, dan dokumentasi. Observasi atau pengamatan merupakan suatu teknik untuk mengumpulkan data dengan jalan menadakan pengamatan terhadap kegiatan yang sedang berlangsung. ${ }^{9}$ Teknik ini digunakan untuk mengetahui secara jelas gambaran dan hal-hal yang berhubungan dengan penelitian di Madrasah Tsanawiyah Darul Amanah. Dalam hal ini penulis mengadakan pengamatan langsung terhadap objek penelitian berupa observasi partisipasi pasif artinya peneliti datang di tempat yang kegiatan yang diamati, namun tidak terlibat dalam kegiatan tersebut. Interview/wawancara merupakan pertemuan dua orang atau kelompok untuk bertukar informasi dan ide melalui tanya jawab, sehingga dikonstruksikan makna dalam suatu topik tertentu dengan tujuan untuk menghimpun data yang ingin di ketahui. ${ }^{10}$ Teknik ini dilakukan dengan mengadakan tanya jawab langsung untuk memperoleh data tentang penelitian penulis. Wawancara yang dilakukan penulis kepada Responden dan informan dengan pedoman wawancara yang sudah ditentukan dengan teknik semiterstruktur. Dokumentasi adalah teknik yang dilakukan dalam pengumpulan data dengan menghimpun dan menganalisis dokumendokumen, baik tertulis, gambar maupun elektronik sesuai dengan penelitian yang dimaksud.

Untuk menganalisis data dalam penelitian ini, penulis menggunakan analisis deskriptif, yaitu dengan mengemukakan data yang diperoleh dalam bentuk penjelasan uraian kalimat dan kemudian

\footnotetext{
${ }^{8}$ Djam'an Satori dan Aan Komariah, Metodologi Penelitian Kualitatif, ( Bandung: Alfabeta, 2012), h. 28

${ }^{9}$ Nana Syaodih Sukmadinata, Metode Penelitian Pendidikan, (Bandung: PT. Remaja Rosdakarya, 2012), Cet ke-8 h. 220

${ }^{10} \mathrm{Ibid}$, h. 216.
} 
Asep Saefuloh, Imaniah Elfa Rachmah, Muhamad Ramli: Implementasi Ekstrakurikuler Dalam Menanamkan Karakter Religius Di Madrasah Tsanawiyah Darul Amanah Desa Pandahan Kecamatan Bati-Bati

mengambil kesimpulan dengan menggunakan teknik logika induktif yakni menarik kesimpulan dari hal-hal yag bersifat khusus kepada hal-hal yang bersifat umum. ${ }^{11}$

\section{HASIL PENELITIAN DAN PEMBAHASAN \\ 1. Implementasi Kegiatan Ekstrakurikuler \\ a. Perencanaan kegiatan}

Siswa (i) Madrasah Tsanawiyah Darul Amanah adalah para remaja. Masa remaja ini sering dianggap sebagai masa peralihan dari masa anakanak kepada masa dewasa. Masa remaja merupakan salah satu masa yang cocok untuk penanaman karakter religius karena pada masa itu mereka memasuki masa yang penuh dengan tantangan yang merupaka jalan untuk mencapai kepribadian yang benar-benar teguh.

Madrasah Tsanawiyah Darul Amanah mengadakan kegiata Ekstrakurikuler dengan harapan agar terbentuk karakter yang baik pada setiap siswa dan menanamkan rasa iman dan taqwa yang merupakan pondasi kehidupan setiap manusia sehingga dapat memperoleh keseimbangan antara ilmu agama dan umum. Dalam hal ini terdapat banyak hal yang direncanakan dalam kegiatan Ekstrakurikuler untuk menanankan karakter religius.

Perencanaan merupakan salah satu hal penting yang perlu dibuat untuk setiap usaha dalam rangka mecapai tujuan. Karena seringkali pelaksanaan suatu kegiatan akan mengalami kesulitan dalam mencapai tujuan tanpa adanya perencanaan.

Kegiatan ekstrakurikuler yang berjalan dengan baik berawal dari perencanaan yang baik pula. Perencanaan kegiatan ekstrakurikuler di Madrasah Tsanawiyah Darul Amanah dibuat oleh dua pembina Ekstrakurikuler, yaitu oleh bapak MN, bapak MR, bapak H setiap awal semester ganjil.

Berdasarkan wawancara penulis mengenai perencanaan kegiatan esktrakurikuler pada tanggal 7 September bersama responden, bapak MN beliau mengatakan terdapat banyak hal yang perlu direncanakan untuk kegiatan ekstrakuirkuler tersebut, maka agar perencanaan dapat diselesaikan dengan efisien bapak MN dan MR berbagi tugas dalam menyelesaikannya.

Bapak MN bertugas mengadakan pendaftaran ekstrakurikuler, membuat absen kelas, menentukan mata pelajaran yang akan diajarkan, memesan kitab yang akan dipelajari sesuai dengan jumlah siswa yang memesan. Dalam perencanaan bapak MR bertugas untuk menentukan hari

${ }^{11}$ Djam'an Satori dan Aan Komariah, Metodologi Penelitian Kualitatif, (Bandung: Alfabeta, 2012), h. 29

Al Qalam: Jurnal Ilmiah Keagamaan dan Kemasyarakatan Vol. 14, No. 1, Januari-Juni 2020 
Asep Saefuloh, Imaniah Elfa Rachmah, Muhamad Ramli: Implementasi Ekstrakurikuler Dalam Menanamkan Karakter Religius Di Madrasah Tsanawiyah Darul Amanah Desa Pandahan Kecamatan Bati-Bati

pelaksanaan kegiatan ekstrekurikuler, membuat jadwal mengajar, dan menyusun kegiatan keagamaan selama kegiatan ekstrakurikuler. ${ }^{12}$

Dengan demikian dapat dikatakan bahwa, pembina kegiatan ekstrakurikuler yaitu bapak MN, Bapak MR dan Bapak H, telah bersamasama membuat perencanaan kegiataan ekstrakurikuler. Perencanaan yang dilakukan antara yaitu, mengadakan pendaftaran, membuat absen kelas, menentukan mata pelajaran yang akan dipelajari, memesan kitab, menentukan hari pelaksanaan kegiatan, membuat jadwal mengajar, dan menyusun kegiatan keagamaan. Perencanaan tersebut dapat dikategorikan sebagai langkah-langkah yang dilakukan dalam reangka mencapai tujuan. Hal ini sesuai dengan panduan pengembangan diri yang diterbitkan oleh Direktorat Pembinaan SMA, tahun 2010 BAB III butir A 4-6 Perencanaan kegiatan ekstrakurikuler mengacu pada jenis-jenis kegiatan yang memuat unsur-unsur sasaran kegiatan, substansi kegiatan, waktu pelaksanaan kegiatan, serta keorganisasiannya, tempat dan sarana.

\section{b. Pelaksanaan kegiatan}

Setelah melaksanakan tahap perencanaan kegiatan ekstrakurikuler, maka tahap selanjutnya adalah dengan melaksanakan program-program kegiatan yang sudah direncanakan sebelumnya baik berupa kegiatan pembelajaran dan keagamaan pada ekstrakurikuler. Berdasarkan hasil wawancara bersama responden, bapak MN, MR dan $\mathrm{H}$ serta hasil observasi peneliti mendapati pelaksanaan kegiatan esktrakurikuler terlaksana dengan dua kegiatan utama yaitu kegiatan pembelajaran dan kegiatan keagamaan sebagaimana yang telah direncanakan pembina ekstrakurikuler. Kegiatan ekstrakurikuler dilaksanakan pada hari Jumat dan Sabtu. Sejak pukul 14.00 WITA siswa (i) mulai berdatangan memenuhi kelas yang telah ditentukan, untuk kelas VII maka siswa dan siswi dipisah pada dua kelas yang berbeda dan untuk kelas VIII siswa (i) bergabung dalam satu kelas, dengan begitu kegiatan ekstrakurikuler ini menggunakan tiga kelas dengan masingmasing murid dalam satu kelas kurang lebih 20 siswa.

Kegiatan pembelajaran kitab kuning dimulai ketika waktu menunjukkan pukul 14.30 WITA dimulai dengan membaca do'a sebelum belajar yaitu surah Alfatihah yang dibaca bersama-sama dengan niat memberi hadiah pahala kepada penulis kitab agar mempermudah pemahaman pada kitab yang telah dikarang penulis. Kegiatan esktrekurikuler dalam satu harinya mempelajari dua kitab kuning dengan alokasi waktu keseluruhan 90 menit dengan rincian: 40 menit untuk pelajaran pertama, 10 menit untuk pergantian pelajaran dan 40 menit

${ }^{12}$ Bapak MN/Pembina Kegiatan Ekstrakurikuler, Wawancara Pribadi, Madrasah Tsanawiyah Darul Amanah Desa Pandahan Kecamatan Bati-bati 7 September 2019

Al Qalam: Jurnal Ilmiah Keagamaan dan Kemasyarakatan Vol. 14, No. 1, Januari-Juni 2020 
Asep Saefuloh, Imaniah Elfa Rachmah, Muhamad Ramli: Implementasi Ekstrakurikuler Dalam Menanamkan Karakter Religius Di Madrasah Tsanawiyah Darul Amanah Desa Pandahan Kecamatan Bati-Bati

selanjutnya untuk pelajaran kedua. Pembelajaran ekstrekurikuler yang dilaksanakan di siang hari sedikit banyaknya tentu mempengaruhi konsentresi siswa (i) ketika belajar. Mengingat hal tersebut pembina kegiatan ekstrakurikuler selain berusaha untuk menyampaikan materi kitab kuning, juga berusaha menyisipkan kisah-kisah Islami, cerita motivasi, nasihat nasihat keagamaan. Melalui hal-hal tersebut selain diharapkan dapat menghilangkan rasa kantuk juga pada muaranya bermaksud memberikan wawasan mengenai ajaran Islam dalam bentuk cerita.

Pemberian nasihat, kisah-kisah Islami, motivasi tentu bukan hanya untuk diketahui siswa (i) saja, melainkan untuk diaplikasikan dalam kehidupan. Pembina kegiatan, Sejak siswa (i) datang untuk memasiki ruangan kelas hingga pada waktu pulang nantinya berusaha mengajak siswa untuk mengamalkan nasihat, dan kisah, dan motivasi secara langusng, seperti ketika melihat siswa yang makan dan minum sambil berdiri maka pembina akan menegur dan meminta untuk duduk serta mengingatkan untuk tidak makan dan minum sambil berdiri dilain waktu. Pelajaran kedua diakhiri dengan kegiatan mengabsen dan membaca doa penutup pelajaran. Kegiatan tersebut dipimpin langsung oleh pembina yang mengajar di kelas tersebut. Dengan berakhirnya pembelajaran kitab kuning yang ditutup dengan do'a, maka seanjutnya pembina meminta, siswa (i) saling bantu untuk menjadikan ruangan kelas sebagai mushola dengan cara menempatkan meja dan kursi dekat ke dinding hingga terciptalah tempat kosong ditengah kelas yang digunakan untuk kegiatan keagamaan.

Kegiatan keagamaan memang diprogramkan terlaksana sebagai penutup kegiatan ekstrakurikuler. Dalam pelaksanaannya kegiatan keagamaan memiliki alokasi waktu 30 menit dan mencakup dua kegiatan, yaitu: salat asar berjamaah dan tilawah Alquran bersama. Salah satu kelebihan melaksanakan kegiatan keagamaan sebelum mengakhiri kegiatan ekstrakurikuler adalah agar siswa (i) merasakan kelapangan batin karena telah menunaikan kewajiban mereka sebagai hamba Allah dan ditambah dengan ibadah sunah berupa tilawah Alquran. ${ }^{13}$

Pada akhir kegiatan tilawah Alquran siswa (i) bersama membaca

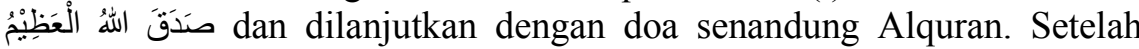
merapikan peralatan shalat serta meletakkan kembali mushaf Alquran yang telah dibaca, pembina meninta siswa (i) kembali saling membantu untuk menempatkan meja dan kursi kembali ke tempat semula. Kemudian, siswa mencium tangan para pembina dan saling bersalaman satu sama lain. Kemudian siswa (i) diperkenankan untuk pulang.

${ }^{13}$ Bapak MN/Pembina Kegiatan Ekstrakurikuler, Wawancara Pribadi, Madrasah Tsanawiyah Darul Amanah Desa Pandahan Kecamatan Bati-bati 7 September 2019.

Al Qalam: Jurnal Ilmiah Keagamaan dan Kemasyarakatan Vol. 14, No. 1, Januari-Juni 2020 
Asep Saefuloh, Imaniah Elfa Rachmah, Muhamad Ramli: Implementasi Ekstrakurikuler Dalam Menanamkan Karakter Religius Di Madrasah Tsanawiyah Darul Amanah Desa Pandahan Kecamatan Bati-Bati

Berdasarkan wawancara dengan informan yaitu kepala Madrasah Tsanawiyah Darul Amanah Bapak $\mathrm{R}$ beliau mengungkapkan, ekstrakurikuler memang terlaksana setiap hari jumat dan sabtu setiap minggunya, berisikan pelajaran kitab kuning dan juga kegiatan keagamaan ${ }^{14}$.

Mengenai pelaksanaan kegiatan keagamaan, beliau juga mengungkapkan bahwa dalam pelaksanaan kegiatan keaagamaan pada ekstrakurikuler, siswa (i) memang masih berada pada tahap pembiasaan, sehingga pihak pembina tentunya akan memberikan bimbingan dan teguran dalam pelaksanaannya ${ }^{15}$.

Berdasarkan hal tersebut maka dapat diketahui bahwa kegiatan ekstrakurikuler terlaksana berdasarkan rencana yang telah disusun sebelumnya, hal ini sesuai dengan pendapat Aswani Sujud yang menyatakan bahwa pelaksanaan merupakan kegiatan melaksanakan apaapa yang telah direncanakan. ${ }^{16}$

Kegiatan ekstrakurikuler yang peulis paparkan di atas dapat dirangkum menjadi beberapa poin kegiatan sebagai berikut:

1) Kegiatan berdoa sebelum dan sesudah kegiatan

Berdoa merupakan kegiatan keagamaan yang berkenan dengan keimanan terhadap Allah SWT. Berdoa sebelum dan sesudah belajar serta akhir kegatan merupakan kegiatan rutin yang dilakukan oleh siswa (i) dalam ekstrakurikuler . Kegiatan berdoa sebelum dan sesudah belajar dipimpin oleh pembina kegiatan dikelas masing-masing

Berdoa dalam ajaran Islam merupakan kegiatan wajib, karena seseorang yag berusaha tanpa berdoa termasuk orang yang sombong dan Allah SWT memperkenankan dan menolong orang yang berdoa sebagaimana dalam surah Al-Baqarah ayat 186 berikut:
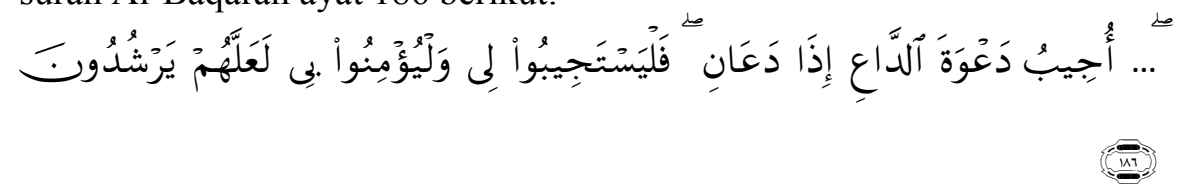

Artinya: "Aku mengabulkan permohonan orang yang berdoa apabila ia memohon kepada-Ku, maka hendaklah mereka itu memenuhi (segala

${ }^{14}$ Bapak R/Kepala Madrasah Tsanawiyah Darul Amanah, Wawancara Pribadi, Madrasah Tsanawiyah Darul Amanah Desa Pandahan Kecamatan Batibati 10 September 2019.

${ }^{15}$ Bapak R/Kepala Madrasah Tsanawiyah Darul Amanah, Wawancara Pribadi, Madrasah Tsanawiyah Darul Amanah Desa Pandahan Kecamatan Batibati 10 September 2019.

${ }^{16}$ Hartati Sukirman Dkk, Administrasi dan Supervisi Pendidikan, (Yogyakarta: UNY Press, 2007) h. 7 
Asep Saefuloh, Imaniah Elfa Rachmah, Muhamad Ramli: Implementasi Ekstrakurikuler Dalam Menanamkan Karakter Religius Di Madrasah Tsanawiyah Darul Amanah Desa Pandahan Kecamatan Bati-Bati

perintah-Ku) dan hendaklah mereka beriman kepada-Ku, agar mereka selalu berada dalam kebenaran." (Q.S. Al-Baqarah: 186)

Oleh karena itu berdoa merupakan kegiatan yang sangat penting dilakukan dan dibiasakan bagi semua peserta didik dalam mengikuti kegiatan ekstrakurikuler ini.

2) Kegiatan bersalaman mencium tangan guru

Mencium tangan merupakan sebuah kegiatan yang mencerminkan rasa menghormati bagi orang yang lebih tua. Mencium tangan juga mampu menjadi sebuah sarana penyampaian kasih sayang terhadap keluarga atau orang yang disayangi. Sikap menghormati orang yang lebih tua juga tertera dalam surah Al Israa' ayat 24:

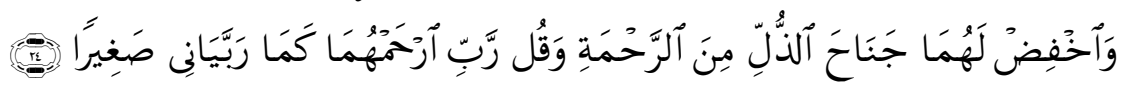

Artinya: "Dan rendahkanlah dirimu terhadap mereka berdua dengan penuh kesayangan dan ucapkanlah: "Wahai Tuhanku, kasihilah mereka keduanya, sebagaimana mereka berdua telah mendidik aku waktu kecil." (Q.S. Al-Isra': 24)

Berjabat tangan kepada sesama merupakan kegiatan yang mencerminkan rasa persaudaraan dan pertemanan. Dalam Islam pertemanan yang terpuji adalah pertemanan dalam dalam hal-hal kebaikan. Allah mengingatkan tentang sikap pertemanan dalam hal kebaikan tertera pada surah Az-Zukhruf: ayat 67:

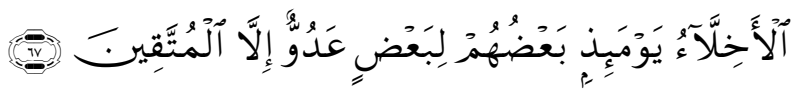

Artinya: "Teman-teman akrab pada hari itu sebagiannya menjadi musuh bagi sebagian yang lain kecuali orang-orang yang bertakwa." (Q.S. AzZhukhruf: 67)

Mencium tangan guru dan saling berjabat tangan ini dilaksanakan setelah siswa (i) selesai mengikuti seluruh rangkaian kegiatan, yaitu sebelum siswa (i) pulang ke rumah masing-masing.

3) Kegiatan bertukar salam

Kegiatan mencium tangan guru dan saling berjabat tangan dengan sesama diikuti pula dengan saling bertukar salam. Dalam ajaran Islam dianjurkan bagi seseorang ketika bertemu maupun hendak perpisah untuk mengucap salam kepada saudara seiman dan seagama dengan mengucapkan Assalamualaikum warahmatullahi wabarakatuh, dan wajib hukumnya bagi yang diberi salam untuk menjawab salam yang diterima. Mengenai kegiatan bertukar salam tertera Alquran pada surah An-Nisa ayat 86 menyebutkan: 
Asep Saefuloh, Imaniah Elfa Rachmah, Muhamad Ramli: Implementasi Ekstrakurikuler Dalam Menanamkan Karakter Religius Di Madrasah Tsanawiyah Darul Amanah Desa Pandahan Kecamatan Bati-Bati

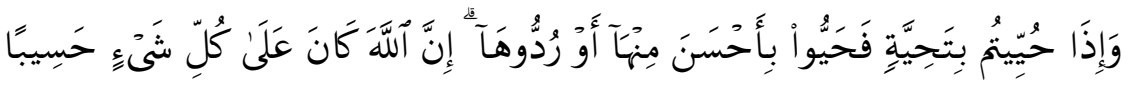

Artinya: "Apabila kamu diberi penghormatan dengan sesuatu penghormatan, maka balaslah penghormatan itu dengan yang lebih baik dari padanya, atau balaslah penghormatan itu (dengan yang serupa). Sesungguhnya Allah memperhitungankan segala sesuatu." (Q.S. An-Nisa: 86).

Kegiatan saling bertukar salam merupakan kegiatan yang sudah dibiasakan bagi peserta didik baik ketika berjabat tangan sebelum pulang, maupun ketikan kegiatan pembelajaran akan dimulai. Kegiatan saling bertukar salam bertujuan untuk menanamkan rasa kekeluargaan dan persahabatan terhadap pembina maupun sesama teman.

4) Kegiatan pembelajaran kitab kuning

Kegiatan pembelajaran kitab kuning merupakan kegiatan inti pada kegiatan ekstrakurikuler. Melalui kegiatan pembelajaran kitab kuning siswa (i) diajarkan berbagai pengetahuan agama dari akidah, fiqih, tajwid, nahwu serta sharaf. Tujuan mempelajari kitab kuning ini adalah untuk memperdalam pengetahuan agama para siswa (i). Allah memuliakan orang yang berilmu dalam surah Fathir ayat 28:

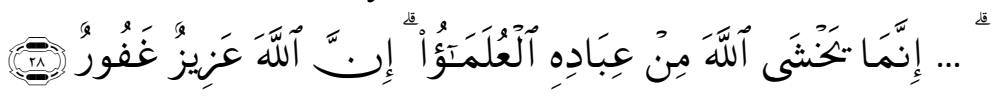

Artinya: "Sesungguhnya yang takut kepada Allah di antara hamba-hambaNya, hanyalah ulama. Sesungguhnya Allah Maha Perkasa lagi Maha Pengampun.” (Q.S. Al-Fathir: 28).

Melalui kegiatan pembelajaran kitab kuning diharapkan siswa (i) dapat memiliki pengetahuan agama yang cukup untuk kehidupan mereka di masa akan datang dan tentunya membantu nilai akademis mereka pada masa belajarnya sekarang.

5) Pendalaman materi

Pendalaman materi merupakan hal yang penting diberikan kepada siswa (i) yang berada paada masa remaja. Masa remaja merupakan masa pencarian jati diri, pada masa ini remaja menjadi labil dan cenderung mengikuti trend zaman. Maka dari hal tersebut pembina kegiatan memberikan pendalaman materi agar mereka memiliki kepribadian muslim sejati dan tidak terjerumus dalam prilaku menyimpang. Allah Berfirman dalam surah Al-Asr' ayat 3:

Al Qalam: Jurnal Ilmiah Keagamaan dan Kemasyarakatan

Vol. 14, No. 1, Januari-Juni 2020 
Asep Saefuloh, Imaniah Elfa Rachmah, Muhamad Ramli: Implementasi Ekstrakurikuler Dalam Menanamkan Karakter Religius Di Madrasah Tsanawiyah Darul Amanah Desa Pandahan Kecamatan Bati-Bati

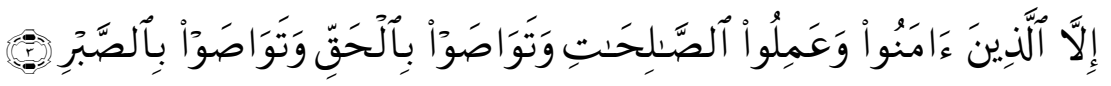

Artinya: "Kecuali orang-orang yang beriman dan mengerjakan amal saleh dan nasehat menasehati supaya mentaati kebenaran dan nasehat menasehati supaya menetapi kesabaran." (Q.S. Asr: 3).

Pemberian pendalaman materi yang juga diikuti pengamalan secara langsung oleh siswa diharapkan dapat menjadi sebuah kebiasaan yang timbul dari dalam diri secara spontan.

6) Kegiatan shalat berjamaah

Shalat merupakan ibadah kepada Allah SWT bagi hamba-hambanya. Shalat terbagi menjadi dua, Shalat fardu dan salat sunah, shalat Asar merupakan salah satu shalat fardu 'ain yang diwajibkan kepada setiap pribadi muslim baik laki kali dan perempuan. Ibadah shalat ini memiliki batas waktu untuk melaksanakannya, dalam surah Al-Baqarah ayat 238 disebutkan:



Artinya: "Peliharalah semua shalat(mu), dan (peliharalah) shalat wusthaa. Berdirilah untuk Allah (dalam shalatmu) dengan khusyu'." (Q.S. Al-Baqarah: 238).

Kegiatan ekstrakurikuler dilaksanakan ketika sore hari saat memasuki waktu shalat Asar. Pelaksanaan shalat Asar ketika ekstrakurikuler ini dilaksanakan secara berjamaah. Melalui pembiasaan shalat Asar berjamaah ini diharapkan mampu menumbuhkan kesadaran siswa (i) untuk terbiasa melaksanakan shalat walaupun sedang beraktifitas.

7) Tilawah Alquran

Alquran merupakan kitab suci umat islam yang berisi firman Allah yang diturunkan kepada Nabi Muhammad dengan perantara malaikat jibril untuk dibaca, dipahami, dan diamalkan sebagai petunjuk dan pedoman hidup.

Tilawah Alquran merupakan sarana dan jalan untuk mengamalkan isi Alquran. Membaca Alquran merupakan kegiatan keagamaan rutin yang dilakukan secara bersama-sama oleh seluruh siwa (i). Membaca Alquran sebuah pekerjaan amal shalih yang dibalas dengan pahala yang berlipat ganda, sebagaimana firman Allah pada surah al Al-Fathir ayat 29-30: 
Asep Saefuloh, Imaniah Elfa Rachmah, Muhamad Ramli: Implementasi Ekstrakurikuler Dalam Menanamkan Karakter Religius Di Madrasah Tsanawiyah Darul Amanah Desa Pandahan Kecamatan Bati-Bati

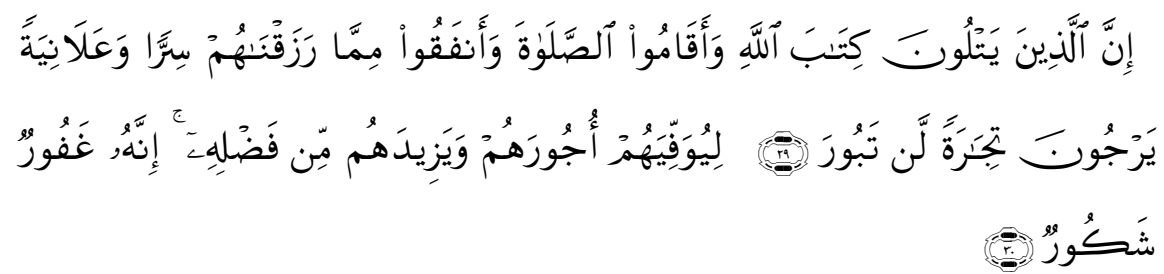

Artinya: "Sesungguhnya orang-orang yang selalu membaca kitab Allah dan mendirikan shalat dan menafkahkan sebahagian dari rezeki yang Kami anugerahkan kepada mereka dengan diam-diam dan terangterangan, mereka itu mengharapkan perniagaan yang tidak akan merugi. Agar Allah menyempurnakan kepada mereka pahala mereka dan menambah kepada mereka dari karunia-Nya. Sesungguhnya Allah Maha Pengampun lagi Maha Mensyukuri.”(Q.S. Al-Fathir: 29-30).

Pembiasaan tilawah Alquran di akhir kegiatan ekstrakurikuler ini diharapkan siswa (i) mampu membiasakan diri melaksanakan berbagai amalan-amalan sunah lainnya, dan terlebih lagi dalam membaca Alquran. Berdasarkan uraian di atas dapat digambarkan jenis kegiatan dan nilai-nilai karakter yang ingin ditanamkan dalam kegiatan eksrakuriler, sebagai berikut:

\section{Tabel Jenis Kegiatan dan Nilai Karakter yang Ditanamkan}

\begin{tabular}{|c|c|c|}
\hline No & Jenis Kegiatan & $\begin{array}{c}\text { Nilai Karakter Yang } \\
\text { Ditanamkan } \\
\end{array}$ \\
\hline 1. & $\begin{array}{l}\text { Kegiatan berdoa sebelum dan } \\
\text { sesudah belajar serta akhir } \\
\text { kegiatan }\end{array}$ & $\begin{array}{l}\text { Iman dan Taqwa, Syukur, } \\
\text { Disiplin dan Tertib. }\end{array}$ \\
\hline 2. & $\begin{array}{l}\text { Kegiatan mencium tangan } \\
\text { guru dan saling berjabat } \\
\text { tangan dengan sesame }\end{array}$ & $\begin{array}{l}\text { Kasih Sayang, Sopan } \\
\text { Menghargai, Ramah } \\
\text { Tenggang Rasa, Disiplin, } \\
\text { Pemaaf, Hormat, Tertib. }\end{array}$ \\
\hline 3. & Kegiatan bertukar salam & $\begin{array}{l}\text { Kasih Sayang, Sopan, } \\
\text { Menghargai, Ramah, } \\
\text { Tenggang Rasa, Pemaaf, } \\
\text { Hormat, Tertib, Terbuka. }\end{array}$ \\
\hline 4. & $\begin{array}{l}\text { Kegiatan pembelajaran kitab } \\
\text { kuning }\end{array}$ & $\begin{array}{l}\text { Iman dan Taqwa, Syukur, } \\
\text { Disiplin dan Tertib, Teguh, } \\
\text { Gigih, Jujur Bijaksana. }\end{array}$ \\
\hline 5. & Pendalaman materi & $\begin{array}{l}\text { Ikhlas, Menghargai, Sabar, } \\
\text { Ramah, Sopan }\end{array}$ \\
\hline
\end{tabular}

Al Qalam: Jurnal Ilmiah Keagamaan dan Kemasyarakatan Vol. 14, No. 1, Januari-Juni 2020 
Asep Saefuloh, Imaniah Elfa Rachmah, Muhamad Ramli: Implementasi Ekstrakurikuler Dalam Menanamkan Karakter Religius Di Madrasah Tsanawiyah Darul Amanah Desa Pandahan Kecamatan Bati-Bati

\begin{tabular}{lll}
\hline 6. & $\begin{array}{l}\text { Kegiatan Sholat Asar } \\
\text { Berjamaah }\end{array}$ & $\begin{array}{l}\text { Iman dan Taqwa, Ikhlas, } \\
\text { Syukur, Amanah, Disiplin, } \\
\text { Bertanggung Jawab, Tertib. }\end{array}$ \\
7. Tilawah Alquran & $\begin{array}{l}\text { Iman dan Taqwa, Ikhlas, } \\
\text { Disiplin, Produktif. }\end{array}$ \\
\hline
\end{tabular}

Berdasarkan data yang telah penulis paparkan, setidaknya terdapat dua langkah penanaman kakter religius yaitu melalui:

1) Pemberian pengetahuan

Pemberian pengetahuan merupakan langkah awal dalam menanamkan karakter religius, karena melalui pengetahuan siswa (i) dapat mengenal perbuatan terpuji dan perbuatan tercela. Pemberian pegetahuan dilakukan melalui pemberian materi pelajaran kitab kuning dan pemberian kisahkisah islami, motivasi, dan nasihat-nasihat.

2) Pembiasaan

Selain melalui pemberian pengetahuan karakter religius jua ditanamkan melalui pembiasaan. Pada ekstrakurikuler ini pembiasaan yang dilakukan meliputi, pembiasaan berdoa sebelum dan sesudah belajar serta akhir kegiatan, pembiasaan bertukar salam, pembiasaan mencium tangan guru dan berjabat tangan dengan sesama anggota, kegiatan sholat asar berjamaah dan tilawah Alquran.

Menurut strategi pelaksanaan pendidikan karakter dari kemdiknas yang dikutip oleh Ahmad Tafsir, bahwa pemberian pengetahuan dan pelaksanaan melalui kegiatan pembiasaan merupakan dua dari tiga langkah dalam menanamkan karakter. ${ }^{17}$ Berdasarkan hal tersebut maka dapat diketahui bahwa penanaman karakter religius melalui kegiatan ekstrakurikuler sesuai dengan strategi pelaksanaan pendidikan karakter dari KEMENDIKNAS.

Madrasah Tsanawiyah Darul Amanah secara berkesinambungan terus berpacu dalam meningkatkan kualitas pelayanan pendidikan untuk mengantarkan peserta didik agar menemukan berbagai potensi yang ada pada diri mereka. Sebagai lembaga pendidikan yang bernamakan madrasah, sudah sepatutnya kualitas siswa dan prilaku siswa ini harus diperhatikan karena mengingat output yang akan bersaing dengan dunia luar yang sangat menantang. Dengan adanya upaya yang dilakukan melalui kegiatan ekstrakurikuler ini, para siswa diharapkan akan memiliki tingkat religiusitas lebih baik daripada sebelumnya.

Mengenai kondisi religiusitas siswa penulis melaksanakan wawancara dengan bapak MR. beliau mengungkapkan, walaupun siswa (i)

\footnotetext{
${ }^{17}$ Ahmad Tafsir, Metodologi Pengajaran Agama Islam, (Bandung: Remaja Rosdakarya, 2004), h, 112.
}

Al Qalam: Jurnal Ilmiah Keagamaan dan Kemasyarakatan Vol. 14, No. 1, Januari-Juni 2020 
Asep Saefuloh, Imaniah Elfa Rachmah, Muhamad Ramli: Implementasi Ekstrakurikuler Dalam Menanamkan Karakter Religius Di Madrasah Tsanawiyah Darul Amanah Desa Pandahan Kecamatan Bati-Bati

yang mengikuti kegiatan ekstrakurikuler sudah diberikan ilmu pengetahuan dan kegiatan keagamaan secara rutin, tidak dapat dipungkiri bahwa terdapat siswa (i) yang memiliki kebiasaan yang perlu dibimbing, seperti ketika berdoa, terkadang ada saja siswa (i) yang tidak ikut bersama membaca doa, ada karena keterlambatan, ada juga karena kurang memperhatikan. ${ }^{18}$

Berdasarkan wawancara bersama beberapa siswa (i) yang menjadi responden dan mengikuti esktrakurikuler secara aktif. Siswa (i) mengungkapkan bahwa mereka memiliki perubahan dalam beberapa hal, walaupun begitu mereka memiliki beberapa kebiasaan yang masih perlu dibina lagi. Siswa RAS misalnya, ia mengungkapkan bahwa ia terbiasa membaca doa sebelum dan sesudah belajar ketika mengikuti pelajaran pagi, hal ini karena ia terbiasa ikut berdoa ketika mengikuti kegiatan ekstrakurikuler di sore hari, ketika keluar rumah ia mengucap salam kepada orang tua dan ketika belajar ia bertambah pemaham karena terkadang telah dipelajari secara lebih rinci pada sore hari. Beberapa hal juga memang perlu dibiasakan lagi antara lain ia masih jarang membaca Alquran setiap hari, dan dalam menunaikan solat fardhu masih masih tiga waktu ${ }^{19}$.

Wawancara bersama siswi SR tidak jauh berbeda dengan RAS, ia mengungkapkan bahwa ia terbiasa membaca doa sebelum dan sesudah belajar ketika mengikuti pelajaran pagi, ketika keluar rumah ia mengucap salam kepada orang tua, ia lebih sering membaca Alquran daripada sebelumnya, terdapat peningkatan pemahaman materi pelajaran dan dapat membaca arab melayu. ${ }^{20}$

Berbeda halnya dengan Siswa MA misalnya, ketika malam hari ia lebih rajin membaca quran, patuh terhadap peraturan, hormat terhadap guru dan memahami pelajaran lebih baik karena telah mempelajarinya di waktu sore. Disisi lain ia juga mengungkapkan bahwa ia terkadang lupa untuk membaca doa sebelum dan sesudah belajar di pagi hari, hal ini memang karena ia belum terbiasa membaca doa sebelum dan sesudah belajar di

${ }^{18}$ Bapak MR/Pembina Kegiatan Ekstrakurikuler, Wawancara Pribadi, Madrasah Tsanawiyah Darul Amanah Desa Pandahan Kecamatan Bati-bati 7 September 2019.

${ }^{19}$ RAS/Siswa yang Mengikuti Kegiatan Ekstrakurikuler, Wawancara Pribadi, Madrasah Tsanawiyah Darul Amanah Desa Pandahan Kecamatan Batibati 31 Agustus 2019.

${ }^{20} \mathrm{SR} /$ Siswi yang Mengikuti Kegiatan Ekstrakurikuler, Wawancara Pribadi, Madrasah Tsanawiyah Darul Amanah Desa Pandahan Kecamatan Bati-bati 31 Agustus 2019.

Al Qalam: Jurnal Ilmiah Keagamaan dan Kemasyarakatan Vol. 14, No. 1, Januari-Juni 2020 
Asep Saefuloh, Imaniah Elfa Rachmah, Muhamad Ramli: Implementasi Ekstrakurikuler Dalam Menanamkan Karakter Religius Di Madrasah Tsanawiyah Darul Amanah Desa Pandahan Kecamatan Bati-Bati

waktu sore hari, dan terkadang bila hendak ke sekolah ia pamit kepada orang tua ${ }^{21}$.

Siswi SNH mengungkapkan bahwa, ia terbiasa mencium tangan orang tuanya ketika hendak berangkat sekolah, hormat terhadap guru dan ia dapat meresap pelajaran Bahasa arab lebih baik karena mempelajari nahwu dan shorof di sore hari. Disisi lain pula ia mengungkapkan bahwa ia jarang membaca doa ketika sebelum dan sesudah belajar dan jarang membaca Alquran karena belum menjadi kebiasaan yang dilaksanakan. ${ }^{22}$ Menurut informan, yaitu kepala madrasah bapak R beliau mengungkapkan sejak adanya kegiatan ekstrakurikuler siswa (i) lebih hormat, sopan dan patuh terhadap guru yang mengajar. Beliau juga mengungkapkan bahwa dengan berjalannya kegiatan ekstrakurikuler ini siswa (i) dapat mematuhi tata tertib sekolah dengan baik. ${ }^{23}$

Berdasarkan pemaparan mengenai kondisi religiusitas siswa (i) diatas, dapat diketahui bahwa siswa (i) memiliki prilaku positif yang perlu dipertahankan dan prilaku negative yang perlu dibimbing. Berdasarkan table tingkat religiusitas siswa yang telah penulis paparkan pada landasan teori, dapat diketahui bahwa siswa (i) memiliki tingkat religiusitas cukup baik.

\section{c. Evaluasi Kegiatan}

Evaluasi kegiatan ekstrakurikuler dilaksanakan setiap satu semester, sehingga dalam satu tahun ajaran terdapat dua kali evaluasi kegiatan. Pada tahap ini evaluasi dimaksudkan agar kegiatan ekstrakurikuler dapat berjalan secara evektif dan berkesinambungan. Contoh evaluasi yang pernah dilakukan sebelumnya adalah dengan memindah hari pelaksanaan kegiatan ekstrakurikuler yang awalnya dilaksanakan pada hari rabu dan kamis menjadi hari jumat dan sabtu. Pemindahan hari kegiatan ekstrakurikuler menjadi jumat dan sabtu karena mempertimbangkan kondisi fisik dan kesiapan siswa (i) ketika mengikuti kegiatan ekstrekurikuler tersebut. Pada hari rabu dan kamis siswa (i) pulang pada pukul 14.00 sehingga hanya mempunyai waktu 30 menit untuk kembali ke sekolah dan mengikuti kegiatan ekstrakurikuler. Adapun hari jumat dan

${ }^{21} \mathrm{MA} /$ Siswa yang Mengikuti Kegiatan Ekstrakurikuler, Wawancara Pribadi, Madrasah Tsanawiyah Darul Amanah Desa Pandahan Kecamatan Batibati 31 Agustus 2019.

${ }^{22} \mathrm{SNH} /$ Siswa yang Mengikuti Kegiatan Ekstrakurikuler, Wawancara Pribadi, Madrasah Tsanawiyah Darul Amanah Desa Pandahan Kecamatan Batibati 31 Agustus 2019.

${ }^{23}$ Bapak R/Kepala Madrasah Tsanawiyah Darul Amanah, Wawancara Pribadi, Madrasah Tsanawiyah Darul Amanah Desa Pandahan Kecamatan Batibati 10 September 2019.

Al Qalam: Jurnal Ilmiah Keagamaan dan Kemasyarakatan

Vol. 14, No. 1, Januari-Juni 2020 
Asep Saefuloh, Imaniah Elfa Rachmah, Muhamad Ramli: Implementasi Ekstrakurikuler Dalam Menanamkan Karakter Religius Di Madrasah Tsanawiyah Darul Amanah Desa Pandahan Kecamatan Bati-Bati

sabtu siswa (i) memiliki waktu luang yang cukup untuk beristirahat dan bersiap untuk mengikuti kegiatan ekstrakurikuler di sekolah.

Kesiapan fisik dalam mengikuti kegiatan ekstrakurikuler mempengaruhi tingkat kehadiran siswa (i) dan melalui pertimbangan tersebut akhirnya pelaksanaan kegiatan ekstrakurikuler dilaksanakan menjadi hari jumat dan sabtu.

Kegiatan ekstrakurikuler yang pernah di evaluasi lainnya adalah mengenai materi pelajaran, pada awalnya materi pelajaran hanya ada empat, yaitu mengenai akidah, fiqih, nahwu dan shorof. Kemudian dikembangkan lagi dan ditambah dengan satu mata pelajaran lagi yaitu tajwid. Penambahan mata pelajaran ini mempertimbangkan kondisi siswa (i) yang memerlukan bimbingan lebih dalam ilmu tajwid.

Dengan demikian dapat diketahui bahwa evaluasi kegiatan ekstrakurikuler dilakukan sebnayak duakali dalam satu tahun ajaran dengan menanggapi permasalahan dengan membuat alternatif yang cocok untuk mengatasi permasalahan tersebut. Evaluasi terhadap kegiatan dan peserta didik merupakan upaya yang dilakukan untuk tercapainya evektifitas program ekstrakurikuler sehingga kegiatan tersebut berjalan dengan lancar, hal ini sesuai dengan pendapat Eka Prihatin yang mengatakan bahwa evaluasi adalah suatu proses pengumpulan data menganalisis informasi tentang efektifitas dan dampak dari suatu tahap atau keseluruhan program ${ }^{24}$ dengan menggunakan evaluasi model CIPP sebagaimana yang diungkapkan oleh Mardapi ${ }^{25}$

\section{Faktor Pendukung dan Penghambat Implementasi Kegiatan Ekstrakurikuler}

a. Faktor Pendukung

1) Faktor guru

Berdasarkan data temuan peneliti, bahwa pembina kegiatan esktrakurikuler Bapak MN dan MR meliliki latar belakang pendidikan pondok pesantren dan dilanjutkan dengan pendidikan tinggi Strata 1 (S1) dan Bapak $\mathrm{H}$ memiliki latar belakang pendidikan Pondok Pesantren Al Falah Putra kota Banjarbaru. Selain itu beliau juga merupakan bagian dari pengurus masjid (kaum/marbot) masjid Darut Taqwa, Pembataan. ${ }^{26}$

Berdasarkan hal diatas maka pembina kegiatan ekstrakurikuler memiliki latar belakang pendidikan yang sesuai dengan tanggung jawabnya pada

\footnotetext{
${ }^{24}$ Eka Prihatin, Teori Administrasi Pendidikan, (Jakarta: Alfabeta, 2011), h. 164

${ }^{25}$ Djemari Mardapi, Pengukuran Penilaian dan Evaluasi Pendidikanm (Yogyakarta: Nuha Litera, 2012), h. 27

${ }^{26}$ Bapak H/Pembina Kegiatan Ekstrakurikuler, Wawancara Pribadi, Madrasah Tsanawiyah Darul Amanah Desa Pandahan Kecamatan Bati-bati 7 September 2019.
}

Al Qalam: Jurnal Ilmiah Keagamaan dan Kemasyarakatan Vol. 14, No. 1, Januari-Juni 2020 
Asep Saefuloh, Imaniah Elfa Rachmah, Muhamad Ramli: Implementasi Ekstrakurikuler Dalam Menanamkan Karakter Religius Di Madrasah Tsanawiyah Darul Amanah Desa Pandahan Kecamatan Bati-Bati

kegiatan tersebut. Latar belakang pendidikan pembina ekstrakurikuler tersebut dapat dikatakan cukup memenuhi baik secara materi pelajaran yang akan diajarkan dan secara kegiatan keagamaan yang akan dilaksanakan. hal ini juga sesuai dengan pendapat Sudarwan Danim menyatakan bahwa, guru yang sesungguhnya adalah guru yang memiliki sebuah kehususan penguasaan di bidang keilmuan tertentu. ${ }^{27}$ Oleh karena itu, kesesuaian antara ilmu yang dimiliki oleh guru dengan mata pelajaran yang diampu sangatlah penting.

Dengan demikian dapat diketahui bahwa latar belakang pendidikan yang telah ditempuh dapat dikatakan cukup untuk menjadi pembina pada esktrakurikuler tersebut.

2) Kepribadian guru

Berdasarkan data yang penulis dapatkan bahwa Pembina kegiatan ekstrakuirkuler merupakan pribadi yang memiliki sopan santun tinggi, bertanggung jawab dalam menjalankan kegiatan esktrakurikuler, berakhlakul karimah dan menjadi suri tauladan bagi siswa (i). Selama kegiatan ekstrakurikuler, kegiatan keagamaan dipimpin langsung oleh para pembina, hal ini dimaksudkan agar guru menjadi suri tauladan bagi siswa (i), karena ketika memimpin kegiatan maka siswa akan mengerti bahwasanya para pembina bukan hanya memprogramkan kegiatan tanpa menjadi bagian dalam kegiatan tersebut, tetapi juga ikut bertanggung jawab terhadap berjalan lancarnya suatu kegiatan tersebut.

Berdasarkan hal tersebut maka Pembina kegiatan ekstrakurikuler dapat dijadikan suri tauladan bagi siswa (i) pada kegiatan tersebut. hal ini juga telah sesuai dengan pendapat E. Mulyasa yang mengatakan bahwa kompetensi kepribadian adalah kemampuan yang mantap, stabil dan dewasa, arif, menjadi teladan bagi peserta didik dan berakhlak mulia. ${ }^{28}$

3) Faktor lingkungan

Berdasarkan temuan data bahwa lingkungan desa pandahan merupakan lingkungan yang agamis. Kondisi lingkungan yang agamis tentu berpengaruh terhadap perkembangan individu yang ada didalamnya, sehingga dengan keadaan lingkungan tersebut menjadi pengaruh mendukung siswa untuk mengikuti kegiatan ekstrakurikuler tersebut.

Hal ini juga sesuai dengan pendapat Sertain yang dikutip dalam Ngalim Purwanto yang dimaksud dengan lingkungan meliputi kondisi dan alam di

${ }^{27}$ Sudarmawan Danim, Inovasi Pendidikan dalam Upaya Peningkatan Profesionalisme Tenaga Kependidikan, (Bandung: Pustaka Setia, 2002), h. 26.

${ }^{28}$ E. Mulyasa, Standar Kompetensi dan Sertifikasi Guru. (Bandung: PT. Remaja Rosdakarya, 2007), h. 173 
Asep Saefuloh, Imaniah Elfa Rachmah, Muhamad Ramli: Implementasi Ekstrakurikuler Dalam Menanamkan Karakter Religius Di Madrasah Tsanawiyah Darul Amanah Desa Pandahan Kecamatan Bati-Bati

dunia ini yang dengan cara-cara tertentu mempengaruhi tingkah laku kita, pertumbuhan, perkembangan atau life Procces. ${ }^{29}$

\section{b. Faktor Pendukung}

1) Motivasi siswa

Berdasarkan data hasil penelitian bahwa siswa (i) memiliki tingkat motivasi yang rendah hal ini dibuktikan dengan keterlambatan siswa (i) ketika kegiatan ekstrakurikuler tersebut. motivasi yang lemah lainnya terdapat pada lemahnya semangat siswa dalam memenuhi target hafalan shorof dan apabila dipaksa maka kemungkinan tidak hadirnya pada waktu yang lain.

Motivasi siswa (i) yang rendah tidak dapat memunculkan suatu perbuatan yang seharusnya ia lakukan, hal ini sesuai dengan pendapat Muh. Uzer Usman dan Lilis Setiawati yang menjelaskan bahwa motivasi adalah usaha membangkitkan motif-motif sehingga menjadi suatu perbuatan. ${ }^{30}$

\section{2) Minat}

Berdasarkan data yang didapat peneliti bahwa ekstrakurikuler mulai ditinggalkan oleh siswa (i) yang mengikutinya karena siswa (i) lebih memilih esktrakurikuler Pramuka dan PMR yang disukai karena adanya perlombaan dan perkemahan diluar sekolah. Berdasarkan hal tersebut maka ketertarikan siswa yang semakin hari berkurang mengindikasikan bahwa siswa lebih berminat mengikuti kegiatan esktrakurikuler selain hal ini sesuai dengan pendapat Slamito mengenai minat bahwa minat adalah suatu perasaan cenderung atau lebih suka dan rasa ketertarikan pada suatu aktivitas, tanpa ada yang menyuruh. ${ }^{31}$

\section{SIMPULAN}

Berdasarkan uraian di atas sebagai simpulan dari pembahasan penelitian ini maka peneliti dapat mengambil kesimpulan bahwa implementasi kegiatan ekstrakurikuler dalam menanamkan karakter religius di Madrasah Tsanawiyah Darul Amanah Desa Pandahan Kecamatan Bati-bati telah berjalan dengan baik. Adapun kegiatan yang dilaksanakan dan nilai karakter yang ditanamkan adalah: 1) Kegiatan berdoa sebelum dan sesudah belajar serta akhir kegiatan, karakter yang ditanamkan adalah: iman dan taqwa, syukur, disiplin dan tertib; 2) Kegiatan

${ }^{29}$ Ngalim Purwanto, Pisikologi Pendidikan. (Bandung: PT. Remaja Rosdakarya, 2000), h. 72

${ }^{30}$ M.Uzer Usman dan Lilis Setiawati, Upaya Optimalisasi Kegiatan Belajar Mengajar, (Bandung: Rosdakarya, 1993), h. 88

${ }^{31}$ Slameto, Belajar dan Faktor-Faktor yang Mempengaruhinya. (Jakarta: Bumi Aksara, 2011), h.182

Al Qalam: Jurnal Ilmiah Keagamaan dan Kemasyarakatan Vol. 14, No. 1, Januari-Juni 2020 
Asep Saefuloh, Imaniah Elfa Rachmah, Muhamad Ramli: Implementasi Ekstrakurikuler Dalam Menanamkan Karakter Religius Di Madrasah Tsanawiyah Darul Amanah Desa Pandahan Kecamatan Bati-Bati

mencium tangan guru dan saling berjabat tangan dengan sesama, karakter yang ditanamkan adalah: kasih sayang, sopan menghargai, ramah tenggang rasa dan disiplin, pemaaf, hormat dan tertib; 3) Kegiatan bertukar salam, karakter yang ditanamkan adalah: kasih sayang, sopan, menghargai, ramah, tenggang rasa, pemaaf, hormat, tertib dan terbuka; 4) Kegiatan pembelajaran kitab kuning, karakter yang ditanamkan adalah: iman dan taqwa, syukur, disiplin dan tertib, teguh, gigih, jujur dan bijaksana 5) Pendalaman materi, karakter yang ditanamkan adalah: ikhlas, menghargai, sabar, ramah dan sopan; 6) Kegiatan shalat berjamaah, karakter yang ditanamkan adalah: iman dan taqwa, ikhlas, syukur, amanah, disiplin, bertanggung jawab dan tertib; 7) Tilawatil Alquran, karakter yang ditanamkan adalah: iman dan taqwa, ikhlas, disiplin dan produktif.

Faktor-faktor yang mempengaruhi implementasi kegiatan esktrakurikuler di Madrasah Tsanawiyah Darul Amanah yaitu: Pertama, faktor yang mendukung pada implementasi kegiatan ekstrakurikuler dalam menanamkan karakter religius antara lain berasal dari latar belakang dan kepribadian guru yang mengajar pada ekstrakurikuler tersebut serta lingkungan masyarakat yang islami, sehingga pelaksanaan kegiatan esktrakurikuler dalam menanamkan karakter religius dapat berjalan dengan baik. Kedua, faktor yang menghambat pada implementasi kegiatan ekstrakurikuler dalam menanamkan karakter religius antara lain berasal dari siswa, yaitu berasal dari motivasi dan minat siswa sehingga mengakibatkan terhambatnya penanaman karakter religius tersebut.

\section{DAFTAR PUSTAKA}

An-Nawawi, Yahya bin Syarf. (2015). Sahih Muslim bi Syarh an-Nawawi. Beirut: Dar al-Kutub al-Ilmiyah.

Danim, Sudarmawan. (2002). Inovasi Pendidikan dalam Upaya Peningkatan Profesionalisme Tenaga Kependidikan, Bandung: Pustaka Setia.

Departemen Pendidikan Nasional. (2003). Undang-Undang No. 20 Tahun 2003 Tentang Sistem Pendidikan Nasional. Bandung: Citra Umbara.

Majid, Abdul dan Dian Anayani. (2013). Pendidikan Karakter Perspektif Islam. Bandung: PT Remaja Rosdakarya.

Mardapi, Djemari. (2012). Pengukuran Penilaian dan Evaluasi Pendidikan. Yogyakarta: Nuha Litera.

Muchsin, Bashori dan Abdul Wahid. (2009). Pendidikan Islam Kontemporer. Bandung: PT. Reflika Aditama.

Mulyasa, E. (2007). Standar Kompetensi dan Sertifikasi Guru. Bandung: Remaja Rosdakarya.

Prihatin, Eka. (2011). Teori Administrasi Pendidikan. Jakarta: Alfabeta. 
Asep Saefuloh, Imaniah Elfa Rachmah, Muhamad Ramli: Implementasi Ekstrakurikuler Dalam Menanamkan Karakter Religius Di Madrasah Tsanawiyah Darul Amanah Desa Pandahan Kecamatan Bati-Bati

Purwanto, Ngalim. (2000). Pisikologi Pendidikan. Bandung: PT. Remaja Rosdakarya.

Satori, Djam'an dan Aan Komariah. (2012). Metodologi Penelitian Kualitatif. Bandung: Alfabeta.

Satori, Djam'an dan Aan Komariah. (2012). Metodologi Penelitian Kualitatif. Bandung: Alfabeta.

Slameto. (2011). Belajar dan Faktor-faktor yang Mempengaruhinya. Jakarta: Bumi Aksara.

Sukirman, Hartati dkk. (2007). Administrasi dan Supervisi Pendidikan. Yogyakarta: UNY Press.

Sukmadinata, Nana Syaodih. (2012). Metode Penelitian Pendidikan. Bandung: PT. Remaja Rosdakarya.

Tafsir, Ahmad. (2004). Metodologi Pengajaran Agama Islam. Bandung: Remaja Rosdakarya.

Uzer, Moh., dan Lilis. (1993). Upaya Optimalisasi Kegiatan Belajar Mengajar. Bandung: Rosdakarya. 